\title{
Political Battle of Mass Media Critical Discourse Analysis: Suara Partai Masjumi Magazine and Bintang Merah Magazine in 1951
}

\author{
Rhoma Dwi Aria Yuliantri M. Pd \\ A lecturer of History Education Program,UNY Yogyakarta) \\ Dosen Pendidikan Sejarah, FIS UNY \\ rhoma_baq@yahoo.com
}

\author{
Anggit Darmatadara \\ Student of Master of LInguistics Program, Faculty of Cultural Sciences, \\ Universitas Gadjah Mada (UGM) - \\ Mahasiswa S2 Liguistik UGM \\ anggitdarmatadara@gmail.com
}

Abtract

This research finds that the language used by Suara Partai Masjumi and Bintang Merah using direct and clear statement in delivering their own ideology. Both also have contrast differences in the vocabulary choices. Suara Partai Masjumi presents Islamic party using the vocabulary influenced by Islam for instance the use of Arabic language for example Muktamar, Djihad, etc. This magazine also cites holy Al-Qu'ran ayat and brings Islamic leaders inside the articles. In the other hand, Bintang Merah magazine as its party ideology intentionally uses marxis term like revisionis, trotskisme, materialisme, etc. This magaizne cites communism and the communist leader. The intention of their publication is to campaign their ideologis and political party's ideas, they are Partai Masjumi and Partai Komunis. Besides, as the informative magazine, it is also as a material source of their members only to educate their members however in society education it does not give any contributions.

Keywords: Media, History, Critical Disrcourse Analysis, Political Battle

\section{INTRODUCTION}

Indonesian presidential campaign, on July 9th, 2014 has been written as the political history of Indonesia. Apparently, it was the first time for Indonesia faced two president candidates, Prabowo-Hatta and Jokowi-Jusuf Kalla. In pra election, Indonesian people were slightly divided into two blocks on the two candidates. Social media, printed media, electronic media, and mass media took a part and contributed on the important role of the process since they were being a part to support their president candidate. In pra-election, media competed each other to report and somehow overthrew the other block. This depiction shows how important the role of media to influence people's point of view.

The media role in presidential campaign and politic in Indonesia as Indonesia Presidential election in 2014 is not a new issue. This culture had ever ensured in Indonesia when it was first presidential election in 1955. Political party used printed media as the propaganda. Absolutely, each party prepared the media as the propaganda instrument for the campaign. For example are from Suluh Indonesia belonged to PNI (Partai Nasional Indonesia), Partai Sosialis Indonesia (PSI) had Pedoman, Masyumi published Suara Partai Masjumi and Harian Abadi, Partai Komunis Indonesia published Harian Rakjat and Bintang Merah.

Media published by Partai Komunis Indonesia and Partai Masjumi is interested to be studied due to both parties represented from communis-social group and Islamic group. Masjumi is a party which is commanded to dissolute by Soekarno in old older whereas PKI was banned in new order. 
This research is to study about the media role in history and language study to answer questions "how media is used by political party to make propaganda?" It examins Suara Partai Masjumi, a media published by Masjumi Party and Bintang Merah published by PKI. It is important to study through language used by both magazine in order to identify how ideology is purposely reconstructed.

\section{METHODOLOGY}

This research uses Critical Discourse Analysis which connects social practice and language. In micro analysis, there is a lexical choice used in Bintang Merah magazine and Suara Partai Masjumi. In meso analysis, it uses a text formed by intitution, history, and relation. These show ideology which is refered in the form of text. Besides, social practice explains the power and practices which own ideology and power. The analyis formula uses lexical choice - the choice of words used and naming choice to construct the identity (Udasmoro, 2003: 52-56).

\section{FINDING AND DISCUSSION}

\section{A. The Existence of Educational Magazine for Party Members}

After Indonesian independence proclaimed, percisely on November $3^{\text {rd }}, 1945$, government declared the edict known as Edict number X, 1945. Based on The Edict number X, on November $3^{\text {rd }}, 1945$ Political party was officially recognized as a representative of democracy. It was a sign of the existence of democratic country in Indonesia.

Thus at that time, there were establishment of 10 political parties, which are Majelis Syuro Indonesia/Masyumi (7 November 1945), Partai Komunis Indonesia/PKI (7 November 1945), Partai Buruh Indonesia/PBI (8 November 1945), Partai Rakjat Jelata (8 November 1945), Partai Sosialis Indonesia/PSI (10 November 1945), Partai Rakjat Sosialis/PRS (Desember 1945), Partai Katholik Republik Indonesia/PKRI (8 Desember 1945), Persatuan Rakjat Marhein Indonesia/Permai (17 Desember 1945), dan Partai Nasional Indonesia/PNI (29 Januari 1946). Besides, it was overtaken an establishment of other political party towards election ten years ahead.

In 1946, the condition of Republic Indonesia was really in unfortune. The competition of political party was really thight. In 1948-1949, then Soekarno pointed Hatta to lead Emergency Presidential Cabinet which was not responsible to KNIP however to Soekarno as president.

Before first election in 1955, parties began to prepare themselves for the election. Many ways held to attract people using media. Among others which used media as educational instrument for their members are Masjumi published Suara Partai Masjumi and Harian Abadi, and PKI published Harian Rakjat and Bintang Merah. Suara Partai Masjumi and Bintang Merah were published to educate their leaders and members in order to unite vission and mission. Masjumi and PKI are in battle towards election in 1955. Both parties are in battle in the election of 1955 in politic of Indoensia.

\section{A.1 "Suara Partai Masjumi" Voice of Masjumi}

Majelis Syuro Indonesia/Masjumi established on November $7^{\text {th }}, 1945$ was not giving benefit for Islam ideology since the nationalist was positioned marginally. Thus, one of the intention the establishment of the party is to organize the strength and power of islamic people as the media of politic (Delier Noer, 2000: 51). Four Islam organizations included to Masjumi are Muhammadiyah, Nadhatul Ulama, Perserikatan Ummat Islam, and Persatuan Ummat Islam.

Masjumi is political organization which has members spreaded over Indonesia. It was driven that the importance of moslem scholar's role at that time. The members of Masjumi are among from merchants, farmers, industry, etc.

One of the educational and communicative instruments of the party and its members are Suara Partai Masjumi magazine which was established in 1945. This magazine was published by the information department of management board of Partai Masjumi. Initially, this magazine was printed limited and in 1951 the magazine was initially managed the editorial staff and tried to add the number of opinion. 
Suara Partai Masjumi had a logo of a half moon facing upward and the picture of Indonesian island in the hollow of the moon as well as a star on the top. Under Sjarif Usman management, with the editorial staff ; Tamar Djaja and Anwar Rasjid helped by the other twelve authors, one of them is Natsir (the leader of Masjumi 1952), Dr. Sukiman, Mr. Jusuf Wibisono, and etc.

As the educational facility of the party member, this magazine greet the member once a month. There was a late publication also on March and April 1951 and the edition of August - September 1951, only published once in two months.

The writer of the magazine are the party members and the party management. It shows that the domination seen from the contribution of the writers. The article written by Sjarif Usman (SJ.U), Natsir, Sukiman, NJ. Sonario (the member of the writers) frequently were listed in the magazine. The other contributors who had different political ideas or took apart outside the party could not participate in the magazine. The whole pages were evenly consisted 30 pages, written by the membe of the party, and left one page for advertisement.

The rubric of the magazine is contained of "Islamic country element", "party matters", " point of consideration", " from management board" and other political news. The news, presented by the magazine are political news related to the party. Political theme usually presented is about Irian Jaya news. Infrequently, the magazine editorial board presented nwes from Islamic countries news and issues; from Pakistan, Turkey and Marocco.

\section{A.2 "Bintang Merah" the Voice of Partai Komunis Indonesia}

In spite of Masjumi, the establishment of PKI which had experienced unfortune conditions in 1950. "New PKI", it was how people called its party in early 1950's since it needed to rid incident of Madium in 1948.

The incident of Madiun in 1948 happened as the political polarization getting flagrant of oposition group (FDR), the left side was under Amir Syarifuddin of Hatta government manifested in the incident of Delaggu strike (May-July 1948), the convulsing of Sala raise up to in the incident of Madiun. So, the incident of Madiun occurred in 1948. The incident ended up by the decision of eradication of communist by Hatta cabinet. Nine of twenty members of CC PKI were killed. The young communist; Sudisman, Aidit, Lukman and Nyoto succeed escaping from the incident. Then they built PKI in new formation.

They considered the former situation were not beneficial so they used media like magazine as the effective communication as well as educational instrument for the members.

"Bintang Merah kita memberikan sinar tjemerlang menerangi djalan jang harus ditempuh oleh setiap anggota Partai dan kaum Buruh jang sadar akan klasnja." (English Version: "Bintang Merah needs to enlight the way of each member and mad who consider their position") (Latiff, 2014)

Bintang Merah was published bimonthly. It was started to publish on 15 August 1950 with putting logo of hammer and sickle and a star in the center. It was printed in 3000 copies, raised 5000 to 7500 to 10000 copies in the end 1951. It was intended only for PKI members.

The editorial comment was written by PKI leaders; P.Pardede, M.H. Lukman, D.N. Aidit and Njoto. Its office was in Kernolong street 4 -Gambir 4525 Djakarta, published by Sekretariat Agitasi-Propaganda CC PKI. The writers were from the members; Wikana, M.h. Lukma, Aidit, Njoto, Pardede.

It as contained of editorial page, Culture column, with the term Marxis of political news. News were related to political issue, party announcement, news from another country which had same ideology, and communist. The countries written are news as "Berita Partai Komunis Yugoslavia", "Kemenangan2 Rakjat Viet-Nam dan tentaranja"," Masalah2 Strategi dari Peperangan Revoluioner di Tiongkok". They were article about communist leaders like Lenin, Mark, Musso, and Stalin. The political theme was pointed in KMB issue. The average of the publication are 50 pages. However somehow there were late publication in two series for example in January only once published.

\section{B. "Depiction" through Educational Magazine for Party Members}

Both magazine, Suara Partai Masjumi and Bintang Merah, are party magazine which present the issue, deliver point of view, and use political simbols to present its ideology. 
The way to represent both ideology can be identified from the use of lexical choice in editorial article. Besides, it is interesting to recognize that each editorial article in Bintang Merah containing the special diction "Rakjat" with $\mathrm{R}$ in capital letter to greet the people and the readers. However, compared to Suara Masjumi, it prefers to use diction "saudara-saudara" and sometimes "umat Islam" to greet the readers.

The diction "Rakjat" with "R" as the first letter of the word is never used by magazine owned by Islamic Party or Nationalist Party since they prefer use the diction "rakjat". Generally, they like to use the word "saudara-saudara" or "umat Islam". "Saudara-saudara" is the referent to mention people or another person. The word "saudara-saudara" is also used in Soekarno speech (the first president of Republic Indonesia) and by general people at that era. In the other hand, the word "umat Islam" is a referent of specific people pointed moslem.

In addition, Suara Partai Masjumi also uses the word "rakjat" with lowercase rarely. The capital letter of R in the word "Rakjat" is one of the specific symbol. "Rakjat" is written to rebuild the party with people support. It depicts that PKI is a people party and the use of capital letter in the letter "R" in "Rakjat" indicates for a communication strategy. Furthermore, PKI like to represent itself to be egalitarian party.

The word "Rakjat" which is frequently used by PKI is also found in Arab language. In Arabic, "ar-ra'iyyah, means pasture and the shepherd is named ra'in. In Al-Qur'an, the word "ar-ra'iyyah" is none, as it uses "ra'a" in Al-Qur'an (QS. Thaha: 54).

The word "saudara-saudara" used by Suara Partai Masjumi is more local and egalitarian. Egalitarian language is chosen by Suara Partai Masjumi is like "sama rasa sama rata" (English: equal one and another is a jargon used to represent egalitarian for PKI). It shows that both parties pretend to be an egalitarian party which can be for everyone by lexical choices in the magazine article.

Suara Partai Masjumi uses Arabic diction to name itself that refers to Islamic ideology. To show its ideology that is owned Islamic ideology, it labels itself by choosing diction from Islam term for intance "Muktamar" to explain the word "meeting with many people" in Indonesian, "Djihad" means struggling. Bintang Merah refers to communist ideology also labels itself by choosing diction of : marxis" like "klas" and "proletar".

Through Suara Partai Masjumi, news and information presented to the readers clearly, which is the party is managed and how is the ideology. Readers clearly states that the articles is considered as the opponent. The oponent of the country are islamic countries.

Ideology mapping is seen from several news like "Tata Negara Diktaktur (communist)". This article contains two pages or more and explains how communist party works, such as:

"...djika seorang Kominis [sic] dipilih untuk duduk disidang Perwakilan Rakjat, maka orang itu dengan pura2 sadja berdjandji hendak setia pada Undang2 Dasar, sedangkan dalam hatinja hendak menjalankan perintah Moskow saja..." (Suara Partai Masjumi, Mei 1951, №. 5: 23)

(English: "... if a communist is chosen to occupy in people representative trial, so he/she pretends to promise on UndangUndang Dasar however in the deep heart they need to do Moscow's command" (Suara Partai Masjumi, May 1951, No. 5: 23).

Masjumi and PKI are contrast in politic. The provocative language in language style of contemptive produced to dominate the opponent politic that communist party is a bad and dangerous party.

Moreover in the article presented in Bintang Merah dominate the discourse for instance mentioning Masjumi as party which is anti-democracy since it supports the agreement of KMB (Konferensi Meja Bundar), "Jang mempertahankan peraturan ati-demokrasi itu hanjalah Masjumi ber-sama2 dengan Fraksi Demokrat...." (English: those who retain the rules of antidemocracy is Masjumi which go together with Demokrat.... " (Bintang Merah, no. 3, Februray 1951; 55)

Partai Masjumi tries to counter the news reported by Bintang Merah. Then Suara Partai Masjumi presented it to support KMB by stating "Pembatalan KMB djika terjadi tentu akan memberikan pukulan berat terhadapa Bangsa Indonesia dalam perekonomian" (English: "the cancellation of KMB happened precisely would give big effect to Indonesian in accordance with the economy" (Suara Partai Masjumi, January 1951: 3)

Masjumi and PKI in the context of politic are always in contrast both in politic and ideology. Even when Indonesian mass media joined in Barisan Pamela Soekarno (BPS) - an organization to support Soekarno, Masjumi and its mass media was 
not involved in. In 1960, Masjumi stepped out based on Soekarno mandatory (President of Republic Indonesia). Without any pleadings from other islamic organizations, Masjumi needed to stop. Five years after, in $1965 \mathrm{PKI}$ also stopped as it was not beneficial, which is well known as 30 September 65 . This incident was a sign of a change old order government to new order government in Indonesia.

\section{CONCLUSION}

Forming of public opinion in both magazines are clearly seen one way and both does not give platform from the others whose ideology is different. All the media advocacy has clear position and do not hesitate in using language style to dominate its ideology.

Besides, seen from the educational function, both magazines have function for its party of its intention. They drive people not to consider something positive but they drive them into provocation. Finally, they succeed in depicting its own ideology. However, both media succeed to form images of egalitarian ideology by lexical choices and naming. Both media refers to the pioneer and country which have same ideology they have.

\section{BIBLIOGRAPHY}

[1] (Magazine Compilation). n.d. (1951, Januari-June). Bintang Merah.

[2] (Magazine Compilation). n.d. (1951, January-October). Suara Partai Masjumi.

[3] Ibnu Hamad, Konstruksi Realita Politik dalam Media Massa: Sebuah Studi Discourse Analysis terhadap Berita-berita Politik, Jakarta: Granit, 2001.

[4] Latif, Busjarie. 2014. Manuskrip Sejarah 45 Tahun PKI 1920-1965. Bandung: Ultimus.

[5] Udasmoro, Wening. 2014. Kontruksi Identitas Remaja dalam Karya Sastra. Yogykarta: Universitas Gadjah Mada Fakultas IImu Sosial, Sastra Perancis. 